\title{
Los libros sobre Deportes y el fomento de la lectura en el currículo de Educación Física: un análisis del libro de Arthur G. Miller y Virginia Whitcomb (1957)
}

\author{
Books about sports and the development of reading in Physical \\ Education curriculum: an analysis of Arthur G. Miller and Virginia \\ Whitcomb's book (1957)
}

\section{Rafael Guimarães Botelho}

Instituto Federal de Educación, Ciencia y Tecnología de Río de Janeiro (IFRJ), Brasil

\section{Resumen}

Este artículo tiene como objetivos: (a) analizar las actividades propuestas por Miller y Whitcomb para la inclusión y utilización de libros sobre Deportes y el fomento de la lectura en el currículo de Educación Física; (b) identificar las referencias de las obras sobre Deportes presentadas por los autores en su obra de 1957. El objeto de estudio es la clásica obra Physical Education in the elementary school curriculum (Miller \& Whitcomb, 1957). Para llevar a cabo esta investigación se han utilizado dos técnicas distintas: el análisis de contenido y el análisis documental. Respecto a los resultados, el tema del fomento de la lectura y de la literatura aparece en el Capítulo 12 - Artes del Lenguaje, y en el Apéndice B - Libros de Lectura sobre Deportes. Los autores, en la mayor parte del texto del Capítulo 12, hacen hincapié en los juegos infantiles, aunándolos con los libros para el fomento de la lectura y ejemplificando algunas actividades y posibilidades, que pueden desarrollarse a partir de esta relación, tales como: narrar, representar, dramatizar, bailar, cantar y leer historias/cuentos, poemas, versos y canciones de los juegos practicados por los niños. A su vez, el Apéndice $B$ contiene un total de 86 referencias de Libros de Lectura sobre Deportes. En síntesis, todas las actividades presentadas por Miller y Whitcomb, representan un gran avance en la Educación Física del bloque anglófono y una visión prospectiva con relación a la importancia del fomento de la lectura y de la literatura infantil en el currículo escolar de esta área.

Palabras clave: libros sobre deportes; fomento de la lectura; currículo de Educación Física; Arthur G. Miller; Virginia Whitcomb.

\begin{abstract}
This paper has the following aims: (a) to analyse the activities proposed by Miller and Whitcomb to include and use books about sports and the development of reading in Physical Education curriculum; (b) to identify the bibliographies in sports books presented by the authors in their 1957 book. The object of study is the classic book Physical Education in the elementary school curriculum (Miller \& Whitcomb, 1957). To carry out this investigation two different techniques were utilized: the content analysis and the documental analysis. Regarding the results, the subjects of development of reading and literature appear on Chapter 12 - Language Arts and Appendix B - Sports Reading Books. The authors, in the majority of Chapter 12 text, emphasize on children's plays, combining them with books to develop reading and exemplify some activities and possibilities that can be developed from this union, such as: to narrate, to perform, to dramatize, to dance, to sing, and to read stories/short stories, poems, verses and songs from children's plays. The Appendix B contains 86 references in Sports Reading Books. In summary, all activities presented by Miller and Whitcomb represent a great progress
\end{abstract}


in English-speaking Physical Education and a prospective vision regarding the importance of developing reading and children's literature in the school curriculum of this area.

Keywords: Sports books; development of reading; Physical Education curriculum; Arthur G. Miller; Virginia Whitcomb.

\section{A MODO DE INTRODUCCIÓN}

En países con amplia producción de obras sobre Deportes como lo son, por ejemplo, Brasil y España, ya se constata algunos estudios que identifican y analizan las obras de literatura infantil relacionadas con la Educación Física y el Deporte (Botelho, 2014ab). No obstante, las investigaciones históricas acerca de esta producción científica y del fomento de la lectura por medio de la Educación Física son todavía escasas.

Además de relevantes para la historia del Deporte, estos estudios son necesarios en el campo de la Didáctica de la Educación Física. En otras palabras, ignorar u olvidar el origen de esta importante manifestación literaria en el currículo del área es un obstáculo para una fundamentada y cultural práctica en el ámbito escolar.

A título de ejemplo, en Estados Unidos ya se discute el tema en el contexto de la Educación Física, como se puede comprobar por medio de los trabajos de Weiller y Higgs (1989), Gabbei y Clemmens (2005) y Fingon (2011). Sin embargo, se observa que, al igual que los demás países, las investigaciones históricas son aún incipientes.

Una amplia, aunque no exhaustiva, revisión de la literatura internacional en lenguas castellana, portuguesa e inglesa realizada en la tesis doctoral Educación Física y literatura infantil: posibilidades de utilización en el ámbito escolar (Botelho, 2010), reveló que Arthur G. Miller y Virginia Whitcomb en un libro publicado en 1957, han sido uno de los primeros autores en sugerir la utilización de libros sobre Deportes para lectura en el currículo de Educación Física.

Por ende, y en base a todo lo expuesto, se plantean los siguientes interrogantes:

- ¿Cuáles son las actividades propuestas por Miller y Whitcomb para la inclusión y utilización de Libros de Lectura sobre Deportes y para el fomento de la lectura en el currículo de Educación Física?

- ¿Qué referencias de obras presentan Miller y Whitcomb en la publicación de 1957 ? 
Con el fin de contestar a los interrogantes establecidos, este artículo tiene como objetivos:

- Analizar las actividades propuestas por Miller y Whitcomb para la inclusión y utilización de libros sobre Deportes y el fomento de la lectura en el currículo de Educación Física.

- Identificar las referencias de las obras sobre Deportes presentadas por los autores en su obra de 1957.

\section{MATERIALES Y MÉTODO}

\subsection{Tipo de investigación}

Este artículo presenta las características teóricas de una investigación histórica (Thomas, Nelson, \& Silverman, 2012), donde se procura examinar y comprender cómo y por qué los autores de una publicación de 1957 (por lo tanto, 60 años) propusieron la utilización de libros de literatura infantil en el currículo de Educación Física.

\subsection{Técnicas de análisis}

Para llevar a cabo esta investigación histórica se han utilizado dos técnicas distintas: el análisis de contenido y el análisis documental.

\subsubsection{Los análisis de contenido y documental}

Heinemann (2008) recuerda que "para la investigación deportiva y para todas sus subdisciplinas, existe una enorme cantidad de material objeto del análisis de contenido ..." (p. 165) que, según Bardin (2002, p. 23) "[...] es un conjunto de técnicas de análisis de comunicaciones".

A su vez, el análisis documental es “[... . una operación o un conjunto de operaciones encaminadas a representar el contenido de un documento bajo una forma diferente de su forma original, con la finalidad de facilitar su consulta o su localización en una fase posterior" (Chaumier, 1993, p. 17).

Por consiguiente, los análisis empleados permitirán presentar información, contenido, además de páginas originales del objeto de estudio analizado. 


\subsection{Objeto de estudio}

El objeto de estudio analizado es la clásica obra Physical Education in the elementary school curriculum, de Arthur G. Miller y Virginia Whitcomb, publicada en 1957 (fecha de su primera edición) por la Editorial Prentice-Hall, de Estados Unidos de América, que contiene 331 páginas.

\section{FIGURA 1}

Portada del libro y la página del índice general con las indicaciones de los Libros de Lectura sobre Deportes (Miller \& Whitcomb, 1957)

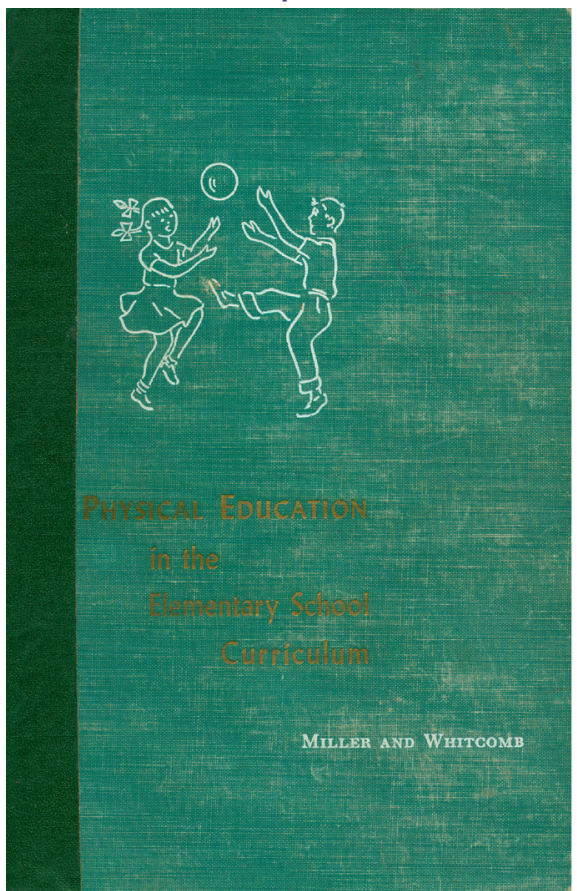

CONTENTS

11. Social Studies (Cont.)

G. Peopless-Eskimos, 268

Related physical education activities, 268. Suggested program, 269. Related classroom activities, 270.
PEoples-The Dutch, 270

H. PEoples-THe Durch, 270
Related physical education activities, 270. Suggested program, 272 .

Related classroom activities, 27

Related physical education activities, 273. Suggested programs, 275.

12. Language Arts . . . . . . . . . . . . 277

A. Lower Grades, 277

Activities in physical education, 279 . Related classroom activities, 280

B. UPPER GraDEs, 281
Activities in physical education, 281. Related classroom activities, 282.

13. Arithmetic . . . . . . . . . . . . . . . . 285

A. Lower Grades, 286

Number concepts, 286. Reading and writing numbers, 288. Addition and subtraction, 288. Measurement, 288. Fractions, 289. Geometric B. UrPER Grades, 290

Number concepts, 290. Addition, subtraction, multiplication, division Number concepts, 290. Addition, subtraction, multiplication, division,
291. Linear measures, 291. Time, 292. Fractions, 292. Percentages and

14. Special Days . . . . . . . . . . . . . . . 294

A. Physical Education Activities, 294

Halloween, 294. Thanksgiving, 295. Christmas, 296. Valentine's Day,

299. Washington's Birthday, 299. Easter, 300. May Day, 301.

B. Reglested Programs, 302

D. Related Refererence, 303

Appendix A. Motion Pictures and Filmstrips . . . . . . . . 305

Selected Producers' List, 305

SPORTS FiLM Guide, 305

Appendix B. Sports Reading Books . . . . . . . . . . . 306

SForts Stohies for Chiddren in Grades II-IV, 306

Spotts Stories Particularly for Girls in Grades IV-VI, 309

Stories WhttTen for Childokn arout Famous Sports Staks, 310 BooKS OF SKILLS AND KNOWLEDGE, 310

\section{RESULTADOS}

El libro de Miller y Whitcomb, importante referencia en el área de Educación Física durante la segunda mitad del siglo XX, está organizado en tres grandes partes: Parte I - Organización y Administración; Parte II - Actividades; Parte III - Integración. Este libro contiene un total de 14 capítulos, tres apéndices y una sección destinada a las referencias bibliográficas.

El tema de los libros de lectura aparece en el Capítulo 12 - Language Arts, que puede ser traducido como Artes del Lenguaje, y en el Apéndice B-Sports Reading Books, que en su traducción literal sería Libros de Lectura sobre Deportes. 


\subsection{Las actividades propuestas por Miller y Whitcomb}

La utilización de Libros de Lectura sobre Deportes tiene mención, por primera vez, en la página 278, segundo párrafo (de la línea 10 a la 18) del Capítulo 12, que tiene ocho páginas (277-284), tal y como se puede observar en la Figura 2.

\section{FIGURA 2}

Portada del Capítulo 12 y de la página 278 (observación: el subrayado en las dos páginas pertenece al autor de este artículo)

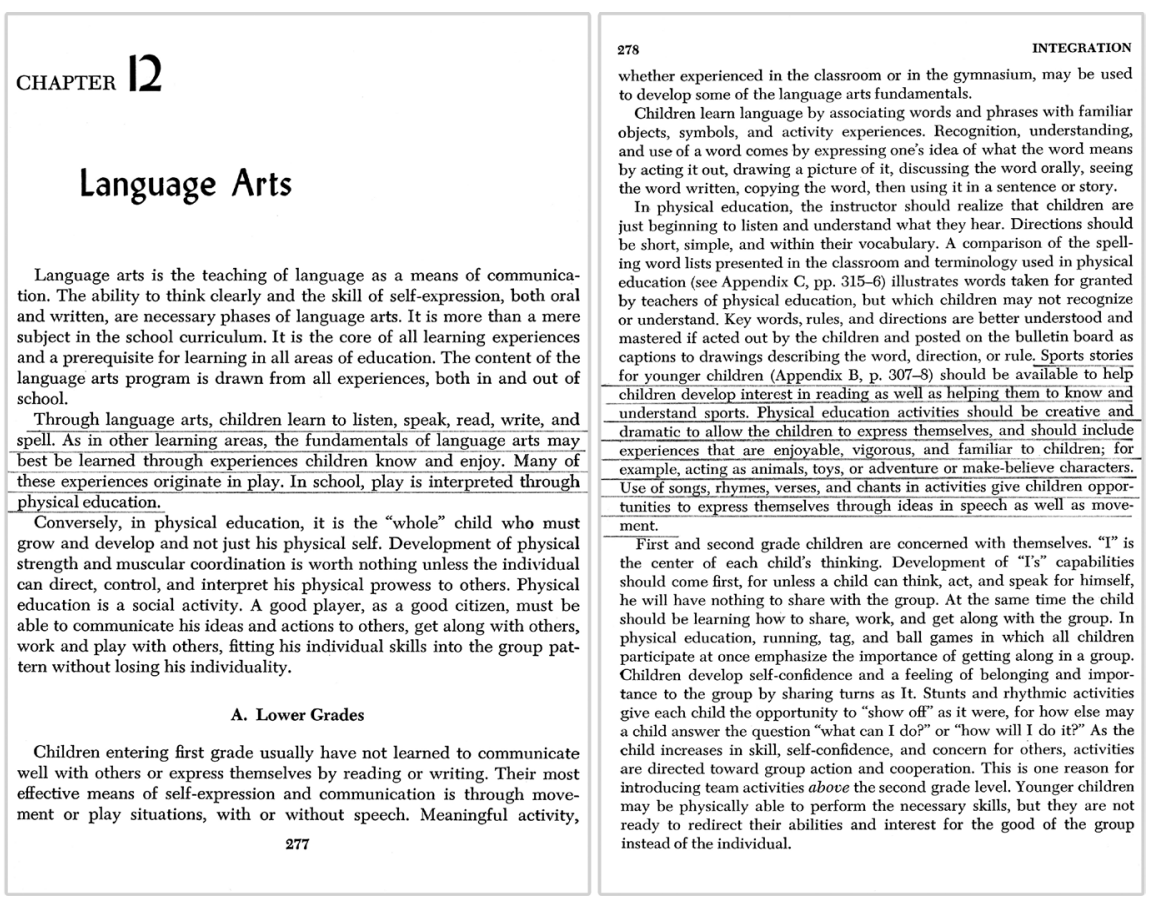

A continuación, se presenta la traducción de la primera mención al tema de los libros sobre Deportes y su respectivo fomento de la lectura:

[...] Las historias infantiles sobre deportes (Apéndice B, p. 307-8) deberían estar disponibles para los niños más pequeños con el fin de fomentar su interés por la lectura, así como ayudarles a conocer y entender los deportes. Las actividades de Educación Física deberían ser creativas y dramatizadas con el fin de que los niños se expresen, y también incluir experiencias divertidas, vigorosas y familiares; por ejemplo, actuar como animales, juguetes, aventureros o personajes imaginarios o de fantasía. Las actividades que incluyen canciones, rimas, versos y cantos ofrecen a los niños la posibilidad de expresarse tanto a través del lenguaje como del movimiento (p. 278). 
Basados en las referencias de los Libros de Lectura sobre Deportes, los autores sugieren algunas actividades que pueden desarrollarse en las clases de Educación Física, a saber:

\title{
FIGURA 3
}

\section{Cuadro con algunas actividades en la asignatura de Educación Física basadas en los Libros de Lectura sobre Deportes (p. 279)}

\section{Actividades en la asignatura de Educación Física}

ORATORIA. Narrar o cantar historias/cuentos, poemas o canciones perfectamente y correctamente, con elegancia y con el tono y pronunciación correctos.

Habilidad para contar una historia a otras personas.

LECTURA. Representar historias, poemas e ideas que han sido leídos a los niños, o que ellos mismos han leído en grupo o individualmente.

Miller y Whitcomb, cuando hablan del lenguaje y su relación con la Educación Física, señalan que:

\begin{abstract}
A través del lenguaje los niños aprenden a escuchar, hablar, leer, escribir y deletrear. Así como en las demás áreas del aprendizaje, los fundamentos del lenguaje pueden ser más fácilmente aprendidos a través de experiencias que los niños ya conocen y disfrutan. Muchas de estas experiencias se originan en juegos, y, en la escuela, el juego se desarrolla por medio de la Educación Física (p. 277).
\end{abstract}

Por ende, si se considera que por intermedio del lenguaje, los niños aprenden cuestiones básicas de comunicación y del juego, desarrolladas en el contexto de la Educación Física, sería un elemento importante para este aprendizaje y una posibilidad más de utilización de las obras infantiles: aplicarlas en los diferentes tipos de juegos que se hacen en las clases de Educación Física.

A continuación, se describen algunas actividades en el aula que ejemplifican diferentes posibilidades del uso de los libros sobre Deportes, del fomento de la lectura e incluso de la literatura infantil en el contexto de los juegos infantiles que se realizan en la Educación Física. 
FIGURA 4

\section{Cuadro con algunas actividades en el aula relacionadas con la Educación Física} (pp. 280-281)

\section{Actividades en el aula relacionadas con la Educación Física \\ COMPRENSIÓN ORAL. Entender las cuestiones e historias relacionadas con los juegos practicados.}

ORTOGRAFÍA. Identificar y reconocer palabras utilizadas en las historias escritas o dibujos sobre el juego realizado. Incluir palabras sobre el juego, títulos, instrucciones y reglas.

LECTURA. Leer libros que presenten actividades relacionadas con juegos que interesen a los niños.

Representar poemas, versos e historias.

Preparar listas de palabras relacionadas con las historias leídas y las actividades practicadas.

Dramatizar, bailar, y representar actividades relacionadas con las historias que han sido leídas. Por ejemplo, al leer una historia sobre indios, los niños podrían remar en una canoa, tocar el tambor, bailar la danza de la guerra o imitar el juego indio descrito.

Miller y Whitcomb ponen de manifiesto la relevancia de la utilización de libros en el currículo de Educación Física cuando afirman que "La lectura de libros sobre deportes (Apéndice B, p. 308) y la investigación de los antecedentes, de la historia y de las técnicas relacionadas con el tema y la materia de estas obras motivan y enriquecen el ámbito de las actividades desarrolladas con los niños" (p. 281).

\subsection{Los Libros de Lectura sobre Deportes (Sports Reading Books)}

El Apéndice B contiene un total de cinco páginas (308-312), que reúnen 86 referencias que los autores llaman Libros de Lectura sobre Deportes. Estas obras están ordenadas según los niveles educativos y otras categorías, tales como: (a) las historias deportivas específicas para chicas; (b) las historias escritas para niños y niñas sobre estrellas del deporte; (c) los libros de habilidades y conocimientos. A continuación, se presentan las cinco páginas que incluyen las referencias de las obras sobre Deportes. 


\section{APPENDIX B}

\section{Sports Reading Books}

\section{Sports Stories for Children in Grades II-IV}

Ayars, James, Jr., Basketball Comes to Lonesome Point, Viking Press, Inc., New York, 1952. A young boy owns the only basketball in town-and offers it to older eighth and ninth grade boys. Story of sportsmanship and building up of a team.

Bonner, M. G., Out to Win, Alfred A. Knopf, Inc., New York, 1947. The story of a little league baseball team.

Winning Dive, Alfred A. Knopf, Inc., New York, 1950. Story of a junior camper in camp sports.

Brewster, Benjamin, First Book of Baseball, Franklin Watts, Inc., New York, 1950. Explains skills, rules, game terminology, records, and standings in young reader's language.

Christopher, Matt, Baseball Pals, Little, Brown \& Company, Boston, 1956.

- Lucky Baseball Bat, Little, Brown \& Company, Boston, 1954. The story of a little boy who wants to learn how to play baseball, starts himself wrong, then learns correctly.

Croggins, Carolyn and Jack Holt, Lance and His First Horse, McGraw-Hill Book Company, Inc., New York, 1949. Delightful, easy to read story about a boy learning to ride. Teaches rules of good riding. Good information for children ages six to eight.

Fishel, Dick and Clair Hare, Terry and Bunky Play Baseball, G. P. Putnam's Sons, New York, 1947. A "How to Play" book, including skills, skill illustrations, and rules.

, Terry and Bunky Play Football, G. P. Putnam's Sons, New York, 1945. A "How to Play" book, including skills, skill illustrations, and rules.

Lindman, Maj, Snipp, Snapp, Snurr Learn to Swim, Albert Whitman \& Company, Chicago, 1955. The adventures of the Swedish triplets during a summer at the seashore, where they learn how to swim and earn achievement awards. 
FIGURA 6

Páginas con los Libros de Lectura sobre Deportes (pp. 309-312)

\begin{abstract}
APPENDIX B

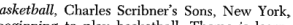
ing to play fair and observe rules. John's Back Yard Camp, Charles Scribner's Sons, New York, 1954
How John and his friends had a wonderful time with a camp in thei own back yard.

N Nicky's Football Team, Charles Scribner's Sons, New York, 1951. A delightful story for seven and eight year olds just beginning to experiment with football.
- Pete's Home Run, Charles Scribner's Sons, New York, 1952, A story or small boys beginning to be interested in best York, 1952. A story , The Shining Shooter, Charles Scribner's Sons, New York, 1950. With prize money in a marble tournament as his goal, Tip decides to lear The game to his best ability.
Todd's Snow Patrol, Charles Scribner's Sons, New York, 1955. About Todd, who lived in the South and had never really seen snow. How
he learned from children in a northern school what fun winter can be with sledding, skiing, and a snow carnival.

Renick, James and Marion Renick, David Cheers the Team, Charles Scribner's Sons, New York, 1942. For younger boys and girls interested in basket-

Football story for younger boys.

\section{Sports Stories for Children in Grades IV-VI}

Archibald, Joe, Double Play Rookie, Macrae Smith Co., Philadelphia, 1955. Johnny, one of the best second basemen in minor leagues, doesn't realize until almost too late that money isn't so important. , Futlback Fury, Macrae Smith Co., Philadelphia, 1955. Fullback seeks
and finds the answer to the question of his own worth as a competitive and finds the answer to the question of his own worth as a competitive
player and a man.

player and a man.
Bishop, Curtis, Larry Comes Home, The Steck Company, Austin, Texas, 1955. Larry's last year in the Little League, by the author of Larry and the Little League and Larry Leads Off. These books describe Larry's ex-
periences and the work of the league.
Howard M., Phantom Backfield, Random House, Inc., New York, 1948. Howard M., Phantom Backfield, Random House, Inc,, New York, 1948
Story about four good high school football players all sent to differen

schools to play-once teammates, now rivals,
Burgoyne, Leon E., Jr., Jack Davis, Forward, The John C. Winston Company,
Philadelphia, 1953. A high school baskethall story.

Philadelphia, 1953. A high school basketball story.
Carrieri, Joe, as told to Zander Hollander, Yankee Bat Boy, Prentice-Hall, Inc., Englewood Cliffs, N.J., 1956. The inside story of the New York Yankees as told through the eyes of a teen-ager, the "luckiest boy in the world" Coombs, Charles, Sleuth at Shortstop, Lantern Press, Inc., New York,
, Young Infield Rookie, Lantern Press, Inc., New York, 1954.

Y Young Readers Baseball Stories, Lantern Press, Inc., New York, 1950. 1951 Young Readers Basebalt Stories, Lantern Press, Inc., New York, 1950.
Young Readers Basketball Stories, Lantern Press, Inc., New York,
\end{abstract}

APPENDIX

311

Renick, Marion, Bats and Gloves of Glory, Charles Scribner's Sons, New York, 1956. How Bruce made his interest, baseball, into just a hobby. , Tha Dooleys Play Ball, Charles Scribner's Sons, New York, 1949. About a lively family that liked to play softball. , Heart for Baseball, Charles Scribner's Sons, New York, 1953. A story of little league baseball.

Skating Today, Charles Scribner's Sons, New York, 1945. A family tory including ice hockey and figure skating.

with solving a mystery Bill learns to sw's Sons, New York, 1947. Along Touchdown for Doc, Charles Scribner's Sons, New York, 1948. Amusing story and introduction to six-man football.

Scholz, Jackson, End Zone, William Morrow \& Company, New York, 1954. Boy at college who has no interest in sports develops interest. An Fielder from Nowhere, William Morrow \& Company, New York, 1948. Big leaguer's story of organizing a baseball team for slum children. Young prize fighter tries to make college football team by using tactics such as conceit and bad temper. While playing, he develops good sportsmanship, and teamwork and shows character development. Stotz, Carl E., At Bat with Little League, Macrae Smith Co., Philadelphia
1952. Story of little league baseball, based on fact.

Tunis, John R., All American, William Morrow \& Company, New York, 1942. Stresses good sportsmanship, tolerance.
Buddy and the Old Pro, William

Old Pro, William Morrow \& Company, New York, High Pockets, William Morrow \& Company, New York, 1948. Base ball player learns that team play is more important than individual glory, World Series, William Morrow \& Company, New York, 1941. Novel of a world series.

\section{Sports Stories Particularly for Girls in Grades IV-VI} Jacobs, Helen Hull, Lt., Laurels for Judy, Dodd, Mead \& Company, Inc., New
York, 1945. Story of a 15 year old girl who discovers sportsmanship
and the will to win needed by a champion in sports.

Johnson, Grace, and Harold Johnson, Kay Ann, McGraw-Hill Book Company, Inc., New York, 1951. Kay Ann's sophomore year in high school-
school dances, games, skijoring, horse show. school dances, games, skijoring, horse show.

napp, Sally, Sink that Basket, Thomas Y. Crowell Company, New York, 1953.

Story of girl's recreational basketball.
Steiner, Charlote, Kiki Dances, Doubleday \& Company, Inc., Garden City, N.Y., 1949. Kiki goes to ballet school. Very interesting to little girls.
Tunis, John R., Champion's Choice, William Morrow \& Company, New York,
1940. Tennis for girls.
310

SPORTS READING BOOKS

Young Readers Football Stories, Lantern Press, Inc., New York, 1950. Young Readers Indoor Sports Stories, Lantern Press, Inc., New York, 1952

,Young Readers Sports Treasury, Lantern Press, Inc, New York, 1952. Young Readers Stories of the Diamond, Lantern Press, Inc., New York, 1956.
Young Readers Water Sports Stories, Lantern Press, Inc., New York, 1952. Young Readers Wat Spots

Decker, Duane, Switch Hitter, William Mor A boy learns to follow directions and cooperate to make big league base-
ball. Emery, R. G., Rebound, Macrae Smith Co., Philadelphia, 1955. A boy and
basketball at West Point. Flood, Richard T., Fighting Southpaw, Houghton Mifflin Company, Boston,

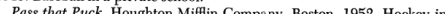
a private school.

, Point After, Houghton Mifflin Company, Boston, 1951. Story of Friendlich, Dick, Baron of the Bull Pen, Westminster Press, Philadelphia, 1955 About Jim, who plans to be a lawyer, and his school baseball team.

Furman, A. L., ed., Young Readers Outdoor Sports Stories, Lantern Press, Inc.,

1950., Young Readers Sports Stories, Lantern Press, Inc., New York,

Harkins, Philip, The Big Silver Bowl, William Morrow \& Company, New York,

Hayes, Florence, Skid, E. M. Hale \& Company, Eau Claire, Wis., 1948. A Negro boy from Georgia finds a place for himself in the new Connecticut environment through his love for baseball and his ability to
play a good game.

Holzman, Robert S., General "Baseball" Doubleday, Longmans, Green \& Company, 1955. The story of the distinguished Civil War general who is
claimed to have invented baseball. Also tells of the Cincinnati Red Stockings, the first successful professional team; development of baseball equipment; starting of leagues; early girls' teams; Doubleday Field; and the Baseball Hall of Fan

Kelley, Robert F., ed., Junior Sports Anthology, Howell, Soskin, Publishers, Inc., 1945. Stories of sports and adventure taken from famous writers such

ch, Tom, Tournament Trail, Lothrop, Lee \& Shepard Company, New York,

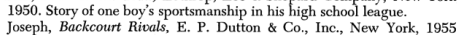

Olgin, Joseph, Backcourt Rivals, E. P. Dutton \& Co., Inc., New York, 1955. About Lefty Allen and Tank Richards, orphanage boys who play for a
junior basketball league. Lefty has a fiery temper and plays as though he lor

Renick, James and Marion Renick, Steady-A Baseball Story, Charles Scribner's situations, - rules, strategy, and skills.

Wyndham, Lee, A Dance for Susie, Dodd, Mead \& Company, Inc., New York, 1953. Includes authentic backgrounds, plausible situations, and ballet , Susie and the Ballet Family, Dodd, Mead \& Company, Inc., New York, 1955 .
Yorsie and the Dancing Cat, Dodd, Mead \& Company, Inc., New
York, 1954 .

Stories Written for Children about Famous Sports Stars

Carmichael, John P., ed., My Greatest Day in Baseball, A. S. Barnes \& Co., Considine, Bob, The Babe Ruth Story, E. P. Dutton \& Co., Inc., New York,

1955.
Feller, Bob, Strikeout Story, A. S. Barnes \& Co., New York, 1947. His story Graham, Frank, Lou Gehrig-A Quiet Hero, G. P. Putnam's Sons, New York,
and Schoor, Gene, Stan Musial Story, Julian Messner, Inc., New York, 1955. and Henry Gilford, Ted Williams Story, Julian Messner, Inc., New York, 1954. An easy reading story.
, Robert, Heroes of Baseball, World Book Company, Yonkers, N.Y., 1953. Smith, Robert, Heroes of Baseball, Worty Book Company, Yonkers, N.Y., 1953.
Unforgettable stories of some fifty men who made baseball history. Van Riper, Guernsey, Jr., Knute Rockne: Young Athlete, from "Childhood of

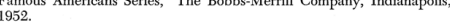
Lou Gehrig: Boy of the Sandlots, from "Childhood of Famous Americans Series," The Bobbs-Merrill Company, Indianapolis, 1949.

Verral, Charles Spain, Mighty Men of Basebal, E. P. Dutton \& Co., Inc., New York, "155, Action-filled story of an all-star team. How each star be-

\section{Books of Skills and Knowledge}

Bonner, Mary, How to Play Baseball, Alfred A. Knopf, Inc., New York, 1955. A practical guide and teaching aid for young readers who want to learn Brown, Conrad, Skiing for Beginners, Charles Scribner's Sons, New York, 1951.

Designed to teach children how to ski correctly.
Martin, W. and J. H. McCullum, How You Can Play Little League Baseball, Prentice-Hall, Inc., Englewood Cliffs, N.J., 1956. A basic book on
fundamentals of baseball for little leaguers. Covers the game, positions, how to play well, coball for little leaguers. Covers the game, positions,

Scott, Barbara Ann and Michael Kirby, Skating for Beginners, Alfred A. Knopf, Inc., New York, 1953. Good pictures and diagrams.
mith, Ken, Baseball's Hall of Fame, A. S. Barnes \& Co., New York, 1947. A 


\subsection{Discusión y aportaciones didácticas al currículo del área de Educación Física}

El primer aspecto a ser discutido se refiere a la nomenclatura utilizada por Miller y Whitcomb en su libro. Ellos emplean términos y expresiones como: (a) Sports stories for younger children (Historias deportivas para los niños pequeños) que, de acuerdo con el contexto de la página 278, fue traducida como Historias infantiles sobre deportes. El Collins Universal: Español-Inglés, English-Spanish: Diccionario bilingüe (2005) también indica el correspondiente cuento al vocablo story, aunque sea mejor empleado cuando se utiliza la palabra inglesa tale. (b) Sports Reading Books (Libros de Lectura sobre Deportes). Dicha nomenclatura, no cabe duda, se refiere, también, al tema de los libros de literatura infantil.

Un segundo tópico de discusión se relaciona con la inclusión de libros sobre Deportes y el fomento de la lectura en un capítulo sobre Artes del Lenguaje. La relación establecida por Miller y Whitcomb entre estas áreas de conocimiento es bastante acertada y facilita el desarrollo de un abanico de posibilidades y actividades en el currículo escolar como, a título de ejemplo, exposiciones artísticas que divulguen el Deporte en la literatura infantil, los libros para lectura relacionados con los Juegos Olímpicos y demás temas específicos de la Educación Física.

Un tercer punto de discusión está circunscrito al tema de los juegos. Los autores, en la mayor parte del texto del Capítulo 12, hacen hincapié en los juegos infantiles, aunándolos con las obras sobre Deportes y ejemplificando algunas actividades y posibilidades que pueden desarrollarse a partir de esta relación, tales como: narrar, representar, dramatizar, bailar, cantar y leer historias/cuentos, poemas, versos y canciones de los juegos practicados por los niños.

Con relación a las aportaciones didácticas al área, la singular obra de Miller y Whitcomb ha sido, probablemente, una de las primeras en presentar la posibilidad de utilizar los libros sobre Deportes y el fomento de la lectura en las actividades curriculares de la asignatura de Educación Física. Por consiguiente, lo que parece una actividad reciente e incluso innovadora para muchos maestros e investigadores de los bloques lusohablante e hispanohablante, era un relevante material literario propuesto e indicado para utilización en clases de Educación Física en el ámbito de la lengua inglesa desde hace más de medio siglo. 


\section{A MODO DE CONCLUSIÓN Y RECOMENDACIONES PARA FUTURAS INVESTIGACIONES HISTÓRICAS}

Por todo lo expuesto, se puede considerar que este texto contribuye a establecer un importante marco histórico en el estudio de los libros de lectura (sean obras infantiles o juveniles) relacionadas con el Deporte y su utilización en el currículo del área de Educación Física.

En síntesis, todas las actividades presentadas por Miller y Whitcomb representan un gran avance en la Educación Física impartida en el bloque anglófono y una visión prospectiva con relación a la importancia del uso de este tipo de material en esta área. Otras propuestas presentadas por los autores en este libro pueden ser consideradas muy originales, relevantes e incluso visionarias...

Efectivamente, no se puede asegurar que este libro haya sido el primero en hacer mención al uso de obras infantiles y juveniles de lectura sobre Deportes... Sin embargo, Miller y Whitcomb han sido, sin lugar a dudas:

- De los primeros autores en proponer la utilización de obras sobre Deportes y el fomento de la lectura en el currículo de la Educación Física.

- En establecer una sólida relación de la Educación Física con el área de Lenguaje, una vez que incluyeron tópicos como la Literatura Infantil y el Arte a lo largo del libro analizado.

A modo de recomendación, otras investigaciones para profundizar la historia, el origen y desarrollo de la inclusión y utilización de los libros sobre Deportes y del fomento de la lectura y de la literatura infantil en la Didáctica de la Educación Física, deben ser realizadas en el contexto científico de la producción bibliográfica en portugués, castellano e inglés dirigida al profesorado del área.

\section{REFERENCIAS}

Bardin, L. (2002). El análisis de contenido (3. ed.). Madrid: Akal.

Botelho, Rafael Guimarães (2014a). Los enfoques de la literatura infantil relacionada con la Educación Física y el Deporte: un análisis comparativo entre Brasil y España. Retos: Nuevas tendencias en Educación Física, Deportes y Recreación, 25, 68-72. Recuperado de http://retos.org/numero 25/68-72.pdf. 
Botelho, Rafael Guimarães (2014b). Presencia de temas relacionados con la Educación Física y el Deporte en la literatura infantil de Brasil y España: un análisis comparativo. Ágora para la Educación Física y el Deporte, 16(2), 137-153. Recuperado de http://agora-revista.blogs.uva.es/files/2014/12/agora 16 2d guimaraes.pdf.

Botelho, Rafael Guimarães (2010). Educación Física y literatura infantil: Posibilidades de utilización en el ámbito escolar (2 v.). (Tesis doctoral no publicada). Departamento de Didáctica de la Expresión Musical, Plástica y Corporal, Facultad de Ciencias de la Educación de la Universidad Autónoma de Barcelona, España. (Incluye el CD-ROM Banco de libros infantiles de Educación Física y Deporte en España).

Chaumier, J. (1993). Técnicas de documentación y archivo. Barcelona: Oikos-Tau.

Collins Universal: Español-Inglés, English-Spanish: Diccionario bilingüe (2005). (8th ed.). Glasgow: HarperCollins.

Fingon, Joan C. (2011). Integrating children's books and literacy into the Physical Education curriculum. Strategies: A journal for Physical and Sport Educators, 24(4), 10-13.

Gabbei, Ritchie, \& Clemmens, Heidi (2005). Creative movement from children's storybooks: Going beyond pantomine. Journal of Physical Education, Recreation and Dance, 76(9), 32-37.

Heinemann, Klaus (2008). Introducción a la metodología de la investigación empírica en las ciencias del deporte (2. ed. rev. y ampl.). Badalona: Paidotribo.

70 Miller, Arthur G., \& Whitcomb, Virginia (1957). Physical Education in the elementary school curriculum. Englewood Cliffs: Prentice-Hall.

Thomas, Jerry R.; Nelson, Jack K. \& Silverman, Stephen J. (2012). Métodos de pesquisa em atividade física. 6. ed. Porto Alegre: Artmed.

Weiller, Karen H., \& Higgs, Catriona T. (1989). Female learned helplessness in sport: An analysis of children's literature. Journal of Physical Education, Recreation and Dance, 60(6), 65-67. 